\title{
FOREIGN DIRECT INVESTMENT, WORKERS' REMITTANCES AND PRIVATE SAVING IN PAKISTAN: AN ARDL BOUND TESTING APPROACH
}

\author{
Syed Ali RAZA \\ IQRA University, Karachi-75300, Pakistan \\ E-mail: syed_aliraza@hotmail.com \\ Received 23 January 2013; accepted 02 April 2013
}

\begin{abstract}
The objective of this study is to investigate the impact of foreign direct investment (FDI) and workers' remittances on private savings of Pakistan. This study employs ARDL bound testing co-integration approach, rolling window analysis, Granger causality test, Toda and Yamamoto Modified Wald causality test and variance decomposition test. Results indicate the significant positive impact of FDI and workers' remittances on private savings in the long and short run. Causality analyses confirm the bidirectional causal relationship of FDI and workers' remittances with private savings. It is recommended that policy makers should form friendly policies to attract more FDI and workers' remittances in the country which leads to increase private savings in Pakistan. This leads to increase more fund for financial intermediaries to increase domestic investment opportunities in the country. This paper makes a unique contribution to the literature with reference to Pakistan, being a pioneering attempt to investigate the impact of FDI and workers' remittances on private savings of Pakistan by using the long annual time series data and applying more rigorous econometric techniques.
\end{abstract}

Keywords: foreign direct investment, remittances, savings, time series, ARDL co-integration, Pakistan.

JEL Classification: F21, F24, E2.

\section{Introduction}

The term savings describe the unconsumed disposable income which is kept with the intention of stabilizing consumption in some future time. Saving is the key factor which increases future consumption. Private savings contribute in overall growth of any country and economists consider it as a gauge to economic health. When people start to rely on debts either than they saved cash much more pressure is found on the financial institutions which reduce the strength of any nation. We can see a high rate of inflation and imposed taxes throughout the world which is a big threat for the amount to save by an individual and which further reduces the investment to be made in the upcoming future. People do saving in the good times so that they have enough funds in their account for the rainy days which are more likely to come in a very frequent pace in develop- 
ing countries like Pakistan. This issue of insufficient funds leads any country towards poverty which is a big threat for all emerging markets, which are trying to become prosperous and want to be counted as a developed nation of this impulsive world. Pakistan, which is on its developing stage, is facing a very low saving rate since very long this is because of many factors influencing the private saving behavior of the country.

Domestic saving and domestic investment gap are considered as a major hurdle to enhance economic growth in developing countries. Foreign capital inflows become an important source to bridge this gap (Chenery, Strout 1966). Foreign direct investment (FDI) and workers' remittances are proved to be an important source of capital inflow in developing countries. FDI plays as an essential part of economic growth of any country. FDI-Growth nexus based on exogenous growth theory and endogenous theory have been discussed heavily in empirically studies ${ }^{1}$. According to the exogenous growth theory FDI can affect the economic growth by providing the technological development in the host country. On the other hand, endogenous growth theory argues that FDI can affect economic growth by providing the positive and significant spillover effects in human capital and gross domestic production.

Workers' remittances play an important role to increase the disposable income. Workers' remittances have become an increasingly important source of income for the economic growth of countries. For the last two decades, the workers' remittances have grown rapidly in a positive direction. In the last five years, foreign direct investment has fallen sharply due to economic recession in Pakistan whereas, workers' remittances are continuously increasing. Workers' remittances provide an external source of income and play a part to increase in the minimum wage level in developing countries, which leads to increase private savings ${ }^{2}$.

From Table 1 it is clear that private savings, foreign direct investment and remittances are increasing over the period of time. On the other hand, from Figures 1 and 2 do not show any clear sign about the relationship between the growth of private saving with foreign direct investment and remittances. From above scatter diagram analysis and the review of summary statistics, we are not coming up to a concrete conclusion about the effects of foreign direct investment and workers' remittances on private savings in Pakistan.

After reviewing the previous empirical studies, it is found that most of the studies have analyzed the impact of foreign capital inflow on domestic saving or national savings in Pakistan. There is only one recent time study has been found on the impact of foreign capital inflow on private saving in Pakistan conducted by Azam and Shakeel (2012). The basic problem with their study is that their analysis is based on assumption that the data that are being used are stationary. Nowadays, there is convincing evidence that many macroeconomic variables are having non-stationary properties. These types of non-stationary variables may provide spurious results in OLS estimations.

\footnotetext{
${ }^{1}$ Borensztein et al. (1998), Lyroudi et al. (2004), and Pradhan (2010).

2 Raza and Jawaid (2012).
} 
Table 1. Summary statistics

\begin{tabular}{ccccc}
\hline Variables & 1970 's & 1980's & 1990's & 2000's \\
\hline PS & 12.55 & 61.42 & 216.96 & 1081.56 \\
\hline FDI & 0.15 & 1.49 & 16.23 & 145.65 \\
\hline REM & 5.6 & 32.36 & 47.91 & 304.59 \\
\hline
\end{tabular}

Note: All figures are in billion rupees (PK).

The main objective of this study is to examine the relationship between FDI, workers' remittances and private saving in Pakistan. This paper makes a unique contribution to the literature with reference to Pakistan, being a pioneering attempt to investigate the impact of FDI and workers' remittances on private savings of Pakistan by using the long annual time series data for 39 years from 1973 to 2011 and by applying more rigorous econometric techniques.

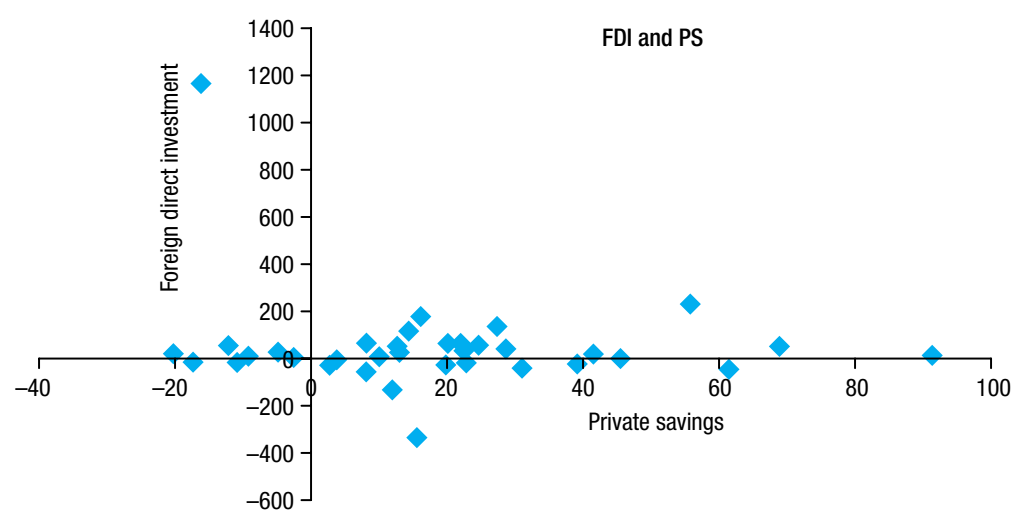

Fig. 1. Foreign direct investment and private savings

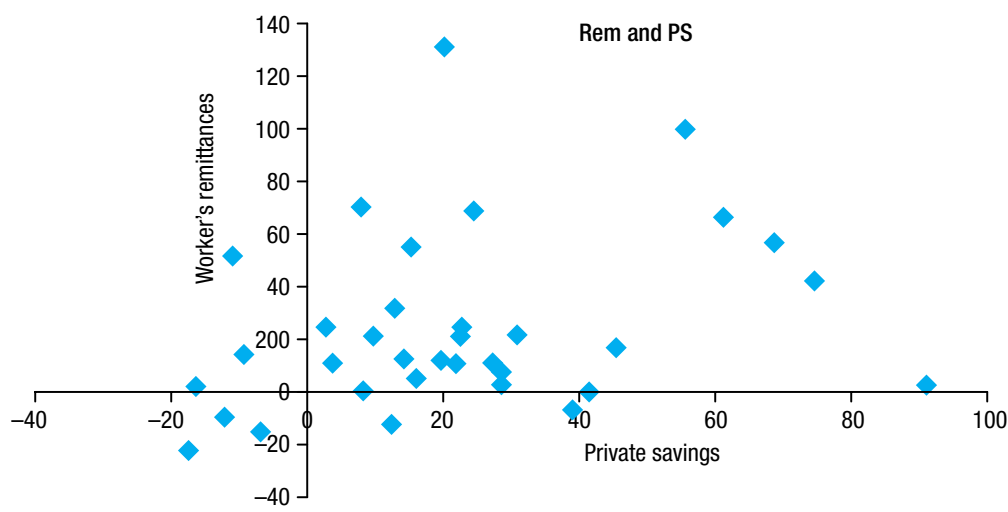

Fig. 2. Worker's remittances and private savings 
The rest of the paper is organized as follows: Section 1 reviews the empirical literature on the relationship between FDI, workers' remittances and private saving. Section 2 discusses the modeling framework; estimations and the results have been discussed in sections $3,4,5$ and 6 , and the final section concludes the study and provides some policy implications.

\section{Review of literature}

Becker's (1974) argue that workers' remittances flow was not profit driven, instead compensatory. Gilani et al. (1981) conclude that most of the workers' remittances in Pakistan are spent on consumption followed by residential investment. Russel (1986) argues that workers' remittances is a main source of savings and investments and also raise the standard of living. Edwards (1996) concludes that workers' remittances contribute positively the saving capacity of household savings. On the other hand, Sofranko and Idris (1999) argue that workers' remittances cannot play a major part in savings because workers' remittances are mainly used for the daily consumption purpose. Adams (1998) concludes that workers' remittances helps to increase the investment by raising the marginal propensity to invest for migrant households in Pakistan.

Kapur and McHale (2003) conclude that workers' remittances may create idleness among recipients because of its compensatory nature. Khan and Hye (2010) identify the impact of financial liberalization on household saving in Pakistan by using the time series data from the period of 1988 to 2008. Autoregressive distributed lag approach has been used. Results indicate the significant positive impact of workers' remittance on household saving in the long run while the results in short run indicate the positive but insignificant relationship between workers' remittances and household saving. Jawaid and Raza (2012) analyze the structure of workers' remittances in China and Korea and conclude that workers' remittances may create voluntary unemployment in the recipients' families which leads to decrease in productivity, growth and savings in the host country.

FDI brings advantages for the enhancement of the standard of living and prospects for economic growth of the host country (see Kindleberger 1969; Dunning 1997; Borensztein et al. 1998; Nair-Reichert, Weinhold 2001; Zhang 2001; Hachicha 2003). Blomstrom and Kokko (1998) analyze the different spillover effects of foreign firms in the economy of the host country. They conclude FDI has a strong spillover effect on the economy of the host country, but the magnitude of spillover effects vary between industries and countries. Edwards (1995) analyzes the panel data of 36 countries from the period of 1972 to 1992 and concludes that domestic saving does not respond with the changes in the foreign capital inflows.

Janicki and Wunnava (2004) analyzed the determinants of FDI in EU countries and conclude that FDI is a major source for rapid economic growth and to increase the living standards of economies in transition. Lipsey and Sjöholm (2004) analyze the relationship between FDI and wages spillover in Indonesian manufacturing industries. They conclude that the presence of foreign entities in Indonesian manufacturing industries 
raises the general wage level in a province and industry. Bowles (1987) analyzes the causal relationship between foreign capital inflows and savings of 20 developing countries from the period of 1960 to 1981. Results indicate the significant causal relationship in 10 countries. He concludes that causal relationships are not universal and it depends on the proportion of the foreign capital inflows.

Ahmad and Ahmed (2002) investigate the impact of foreign capital inflows on domestic saving in Pakistan by using the annual time series data from the period of 1972 to 2000 . Johansen and Jeuuselius' cointegration and error correction model techniques have been used. Results indicate that the foreign capital inflows may play a part as a substitute for domestic saving. Katircioglu and Naraliyeva (2006) investigate the causal relationship between private saving and FDI in Kazakhstan by using the quarterly data from the $1^{\text {st }}$ quarter of 1993 to fourth quarter of 2002. Results of granger causality test confirm the no causal relationship between FDI and private saving.

Bashier and Bataineh (2007) investigate the relationship between FDI and domestic saving in Jordan by using the annual time series data from the period of 1971 to 2005 . Johansen and Jeuuselius cointegration, error correction model and granger causality test have been performed. Results indicate the significant positive impact of FDI on domestic saving. Results of granger causality test confirm the unidirectional causal relationship run from FDI to domestic savings. Shahbaz et al. (2008) investigate the causal relationship between FDI and domestic saving in Pakistan by using the annual time series data from the period of 1972 to 2007. Results of causality test based on Toda and Yamamoto procedure, confirm the bidirectional causal relationship between FDI and domestic saving. It is concluded that FDI and domestic saving are connected in a complementary way.

Salahuddin et al. (2010) analyze the impact of FDI on domestic saving in Bangladesh by using the annual time series data from the period of 1985 to 2007 . Johansen and Jeuuselius cointegration, error correction method and innovation accounting approach have been used. Results indicate the positive and significant relationship between FDI and domestic saving. Results suggest the complementary effect between FDI and domestic saving in Bangladesh. Results of variance decomposition methods indicate the bidirectional causality between FDI and domestic saving.

Oladipo (2010) analyze the causal relationship between FDI and savings in Nigeria by using the annual time series data from the period of 1970 to 2006 . The causality test base on Toda and Yamamoto procedure has been used. Results indicate the unidirectional causal relationship between FDI and savings in Nigeria runs from FDI to savings. Azam and Shakeel (2012) investigate the impact of foreign capital inflow on household savings in Pakistan by using the annual time series data from the period of 1981 to 2010 . The results of multiple regression technique indicate the positive and significant impact of workers' remittances and FDI in household savings.

Faridi and Arif (2012) analyze the relationship between workers' remittances and gross saving in Pakistan during the period of 1972-2010. Results indicate the positive and significant influence of workers; remittances on gross savings in Pakistan. Bayar (2014) 
analyzes the relationship between FDI and domestic savings in emerging Asian economies during the period of 1982-2012. The results of vector error correction methods confirm the significant influence of FDI on domestic savings in emerging Asian economies.

\section{Empirical framework}

In this study, 39 years long annual time series data of Pakistan has been used from 1973 to 2011. Data on private savings, foreign direct investment and remittances are gathered from several issues of economic survey of Pakistan ${ }^{3}$. All variables are used in logarithmic form. The present study employs the Autoregressive Distributed Lag (ARDL) technique ${ }^{4}$ that has not been used previously to analyze the relationship of FDI and workers' remittances with private savings in Pakistan.

The Auto Regressive Distributed Lag (ARDL) method of cointegration developed by Pesaran M. H. and Pesaran B. (1997), Pesaran and Shin (1999), Pesaran et al. (2000, 2001) has been used with the help of unrestricted vector error correction model to investigate the long run relationship between FDI, workers' remittances and private savings. The ARDL approach has several advantages upon other cointegraion methods. ARDL approach may applies irrespective of the of whether underlying variables are purely $I(0), I(1)$ or mutually co-integrated ${ }^{5}$. ARDL approach has estimated better small sample properties ${ }^{6}$. In ARDL procedure the estimations of the results are even possible if the explanatory variable is endogenous ${ }^{7}$. The following ARDL model is developed for estimation:

$$
\begin{aligned}
& \Delta P S_{t}=\psi_{0}+\psi_{1} \sum_{i=1}^{p} \Delta P S_{t-1}+\psi_{2} \sum_{i=1}^{p} \Delta F D I_{t-1}+\psi_{3} \sum_{i=1}^{p} \Delta R E M_{t-1}+\gamma_{1} P S_{t-1}+ \\
& \gamma_{2} F D I_{t-1}+\gamma_{3} R E M_{t-1}+\mu_{t},
\end{aligned}
$$

where $\psi_{0}$ is constant, $\mu_{t}$ is a white noise error term, PS is private savings, FDI is foreign direct investment and $R E M$ is workers' remittances. The error correction dynamics are denoted by the summation sign while the second part of the equation corresponds to the long run relationship. Schwarz Bayesian Criteria $(S B C)$ has been used to identify the optimum lag of model and each series. The SBC is slightly superior to the AIC (Pesaran, Shin 1999). Besides, SBC is parsimonious as it uses minimum acceptable lag while selecting the lag length and avoid unnecessary loss of degrees of freedom. Therefore, SBC criterion has been used, as a criterion for the optimal lag selection, in all cointegration estimations.

In ARDL model we first estimate the $F$-statistics value by using the appropriate ARDL models. Secondly, the Wald ( $F$-statistics) test is used to investigate the long run rela-

\footnotetext{
${ }^{3}$ The web link is: www.finance.gov.pk

${ }^{4}$ See Pesaran M. H. and Pesaran B. (1997), Pesaran and Shin (1999), and Pesaran et al. (2000, 2001).

${ }^{5}$ Pesaran and Shin (1999).

${ }^{6}$ Haug (2002).

${ }^{7}$ Pesaran, Shin (1999) and Pesaran et al. (2001).
} 
tionship between the series. The null hypothesis of no cointegration is rejected if the calculated $F$-test statistics exceeds the upper critical bound (UCB) value. The results are said to be inconclusive if the $F$-test statistics falls between the upper and lower critical bound. Lastly, the null hypothesis of no cointegration is accepted if the $F$-statistic is below the lower critical bound. If the long run relationship between foreign direct investment, workers' remittances and private savings is found, then we estimate the long run coefficients. The following model will be used to estimate the long run coefficients:

$$
P S_{t}=\zeta_{0}+\zeta_{1} \sum_{i=1}^{p} P S_{t-1}+\zeta_{2} \sum_{i=1}^{p} F D I_{t-1}+\zeta_{3} \sum_{i=1}^{p} R E M_{t-1}+\mu_{t}
$$

If we find evidence of long run relationship between foreign capital inflows and private savings, then we estimate the short run coefficients by employing the following model:

$$
\Delta P S_{t}=\varphi_{0}+\varphi_{1} \sum_{i=1}^{p} \Delta P S_{t-1}+\varphi_{2} \sum_{i=1}^{p} \Delta F D I_{t-1}+\varphi_{3} \sum_{i=1}^{p} \Delta R E M_{t-1}+n E C M_{t-1}+\mu_{t} .
$$

The error correction model shows the speed of adjustment needed to restore the long run equilibrium following a short run shock. The $n$ is the coefficient of the error correction term in the model that indicates the speed of adjustment.

\section{Estimations and results}

Augmented Dickey Fuller $(A D F)^{8}$ and Phillip Perron $(P P)^{9}$ unit root test are used to examine the stationary properties for long run relationship of time series variables. Augmented Dickey Fuller $(A D F)$ test is based on the equation given below:

$$
\Delta Y_{t}=\alpha_{0}+\alpha_{1} Y_{t-1}+\sum_{j=1}^{k} d_{j} \Delta Y_{t-j}+\varepsilon_{t},
$$

where $\varepsilon_{t}$ is pure white noise error term, $\Delta$ is a first difference operator, $Y_{t}$ is a time series, $\alpha_{0}$ is the constant and $k$ is the optimum numbers of lags of the dependent variable. Augmented Dickey Fuller $(A D F)$ test determines whether the estimates of coefficients are equal to zero. The $A D F$ test provides cumulative distribution of $A D F$ statistics. The variable is said to stationary, if the value of the coefficient $\delta$ is less than the critical values from fuller table. Phillip and Perron $(P P)$ unit root test equation is given below:

$$
\Delta Y_{t}=\alpha+\rho^{*} Y_{t-1}+\varepsilon_{t}
$$

The Phillip and Perron unit root test is also based on t-statistics that is associated with estimated coefficients of $\rho^{*}$. Table 2 represents the results of stationary tests. First, these tests are applied on level of variables, then on their first difference.

Results of Table 2 show that all variables are stationary and integrated at first difference. This implies that the series of variables may exhibit a valid long run relationship.

\footnotetext{
${ }^{8}$ See Dickey and Fuller (1979).

${ }^{9}$ See Phillips and Perron (1988).
} 
Autoregressive distributed lag method for cointegration is used to estimate the long run relationship between foreign capital inflows and private savings. The first step is to determine the optimal lag length of the model. The order of optimal lag length is decided by using the Schwarz Bayesian Criterion. Table 3 shows the results of the ARDL cointegration method.

The $A R D L$ results suggest the rejection of the null hypothesis of no cointegration in model because the value of the $F$ - statistic is greater than upper bound critical value at $5 \%$ level of significance in favor of alternative hypothesis that the valid long run relationship is exist between FDI, workers' remittances and private savings in Pakistan. Now we estimate the lag length order of the all variables through unrestricted vector auto regression method. The decision criterion is based on the minimum value of Schwarz Bayesian Criterion.

Table 4 represents the results of the lag length order of all variables. Results of Schwarz Bayesian Criterion indicate that FDI and workers' remittances should be include at $1^{\text {st }}$ lag and private savings should be include at $2^{\text {nd }}$ lag. After having the valid evidence of the long run relationship between foreign capital inflows and private savings. Now we applied the $A R D L$ method to estimate the long run and short run coefficients.

Table 2. Stationary test results

\begin{tabular}{ccccccccc}
\hline Variables & \multicolumn{3}{c}{ Augmented Dickey-Fuller } & \multicolumn{3}{c}{ Phillips-Perron } \\
\cline { 2 - 9 } & \multicolumn{2}{c}{$\mathrm{I}(0)$} & \multicolumn{2}{c}{$\mathrm{I}(1)$} & \multicolumn{2}{c}{$\mathrm{I}(0)$} & \multicolumn{2}{c}{$\mathrm{I}(1)$} \\
\cline { 2 - 9 } & $\mathrm{C}$ & $\mathrm{C} \& \mathrm{~T}$ & $\mathrm{C}$ & $\mathrm{C} \& \mathrm{~T}$ & $\mathrm{C}$ & $\mathrm{C} \& \mathrm{~T}$ & $\mathrm{C}$ & $\mathrm{C} \& \mathrm{~T}$ \\
\hline PS & -1.62 & -2.75 & -6.22 & -6.83 & -1.05 & -2.21 & -10.11 & -10.38 \\
\hline FDI & -0.57 & -3.02 & -5.29 & -5.15 & -0.79 & -2.94 & -7.21 & -7.10 \\
\hline REM & -1.70 & -2.94 & -3.44 & -3.38 & -1.32 & -2.13 & -4.15 & -4.18 \\
\hline
\end{tabular}

Note: The critical values for ADF and PP tests with constant (c) and with constant \& trend (C\&T) $1 \%, 5 \%$ and $10 \%$ level of significance are $-3.711,-2.981,-2.629$ and -4.394 , $-3.612,-3.243$ respectively.

Table 3. Lag length selection \& bound testing for cointegration

\begin{tabular}{|c|c|c|c|c|}
\hline Lags order & AIC & HQ & SBC & F-test statistics \\
\hline 0 & 11.177 & 12.223 & 11.313 & 19.321 \\
\hline 1 & 6.177 & 6.223 & 6.313 & \\
\hline 2 & 2.681 & 2.865 & 2.226 & \\
\hline \multicolumn{5}{|c|}{ Critical values generated by Pesaran et al. (2001) } \\
\hline Significance level & Lower bounds & Upper bounds & & \\
\hline $1 \%$ & 6.340 & 7.520 & & \\
\hline $5 \%$ & 4.870 & 5.850 & & \\
\hline $10 \%$ & 4.190 & 5.062 & & \\
\hline
\end{tabular}


Table 4. Lags defined through VAR of variables

\begin{tabular}{ccccc}
\hline Lag & 0 & 1 & 2 & Selected lags \\
\cline { 2 - 5 } & SBC & SBC & SBC & SBC \\
\hline PS & 3.795 & -0.147 & $-0.218^{*}$ & 2 \\
\hline FDI & 4.645 & $1.402^{*}$ & 1.591 & 1 \\
\hline REM & 3.485 & $0.249^{*}$ & 0.313 & 1 \\
\hline
\end{tabular}

Note: * indicate minimum SBC values.

The model for long run coefficients as follows:

$$
\begin{aligned}
& P S_{t}=\zeta_{0}+\zeta_{1} \sum_{i=1}^{p} P S_{t-1}+\zeta_{2} \sum_{i=1}^{p} P S_{t-2}+\zeta_{3} \sum_{i=1}^{p} F D I_{t}+\zeta_{4} \sum_{i=1}^{p} F D I_{t-1}+ \\
& \zeta_{5} \sum_{i=1}^{p} R E M_{t}+\zeta_{6} \sum_{i=1}^{p} R E M_{t-1}+\mu_{t} .
\end{aligned}
$$

Table 5 shows the results of long run $A R D L$ estimations. Results indicate the significant positive impact of FDI and workers' remittances on private savings in Pakistan. The coefficient of FDI showing the higher contribution in the private saving model, that's means that in the long run $1 \%$ increase in FDI causes the increases in the private savings by $0.53 \%$. On the other hand, the coefficient of workers' remittances showing that the $1 \%$ increase in workers' remittances causes the increase in the private savings by $0.25 \%$. It is concluded that FDI and workers' remittances both play an important part in the enhancement of private savings in Pakistan. FDI provides more opportunities of employment conversely, workers' remittances provide an external source of income. Both FDI and workers' remittances play a part to increase in the minimum wage level in developing countries, which leads to increase private savings. Following model is

Table 5. Long run results using ARDL approach

\begin{tabular}{cccc}
\hline Variables & Coeff. & t-stats & Prob. \\
\hline C & 0.563 & 1.738 & 0.093 \\
\hline PS(-1) & 0.509 & 3.472 & 0.002 \\
\hline PS(-2) & 0.390 & 2.440 & 0.021 \\
\hline FDI & 0.533 & 2.303 & 0.034 \\
\hline FDI(-1) & -0.661 & -1.411 & 0.160 \\
\hline REM & 0.250 & 1.909 & 0.066 \\
\hline REM(-1) & -0.249 & -2.043 & 0.050 \\
\hline Adj. $R^{2}$ & & 0.989 \\
\hline D.W stats & 2.312 \\
\hline F-stats (Prob.) & $584.829(0.000)$ \\
\hline
\end{tabular}


Table 6. Short run results using ARDL approach

\begin{tabular}{cccc}
\hline Variables & Coeff. & t-stats & Prob. \\
\hline $\mathrm{C}$ & -0.004 & -0.033 & 0.974 \\
\hline$\Delta \mathrm{PS}(-1)$ & 0.788 & 1.245 & 0.223 \\
\hline$\Delta \mathrm{PS}(-2)$ & 0.327 & 1.035 & 0.310 \\
\hline$\Delta$ FDI & 0.354 & 3.502 & 0.002 \\
\hline$\Delta$ FDI(-1) & -0.321 & -0.576 & 0.569 \\
\hline$\Delta$ REM & 0.358 & 2.985 & 0.006 \\
\hline$\Delta$ REM(-1) & -0.454 & -2.235 & 0.034 \\
\hline ECM(-1) & -0.484 & -2.271 & 0.031 \\
\hline Adj. R & \multicolumn{3}{c}{0.541} \\
\hline D.W stats & 2.105 \\
\hline F-stats (Prob.) & $5.491(0.001)$ \\
\hline
\end{tabular}

used to check the short run relationship among the considered variables with the different lag length.

$$
\begin{aligned}
& \Delta P S_{t}=\varphi_{0}+\varphi_{1} \sum_{i=1}^{p} \Delta P S_{t-1}+\varphi_{2} \sum_{i=1}^{p} \Delta P S_{t-2}+\varphi_{3} \sum_{i=1}^{p} \Delta F D I_{t}+\varphi_{4} \sum_{i=1}^{p} \Delta F D I_{t-1}+ \\
& \varphi_{5} \sum_{i=1}^{p} \Delta R E M_{t}+\varphi_{6} \sum_{i=1}^{p} \Delta R E M_{t-1}+n E C M_{t-1}+\mu_{t} .
\end{aligned}
$$

Table 6 represents the short run relationship between foreign capital inflows and private savings. Results indicate the lagged error correction term for the estimated private savings equation is both negative and statistically significant. This confirms a valid short run relationship between foreign capital inflows and private savings in Pakistan. The coefficient of the error term is -0.48 suggest that about $48 \%$ of disequilibrium is corrected in the current year. Results indicate the significant positive short run relationship of FDI and workers' remittances with private savings. The short run coefficient of workers' remittances showing the higher contribution in the short run model of private savings, that's means that in short run 1\% increase in REM causes the increases in the private savings by $0.45 \%$. On the other hand, the coefficient of FDI showing that the $1 \%$ increase in FDI causes the increase in the private savings by $0.25 \%$ in the short run.

The results of both long run and short run conclude that FDI is contributing more in the long run as compare to short run in increasing of private savings in Pakistan. Conversely, workers' remittances is contributing more in short run as compare to long run in the enhancement of private savings in Pakistan. 


\section{Stability of long run model: a rolling window analysis}

The stability of long run coefficients of the model in the sample size is evaluated by using the rolling window estimation method. This technique also helps to identify the behavior of considered variables throughout the sample period (Raza et al. 2015). Figures 3 and 4 represent the results of coefficients of FDI and workers' remittances respectively:

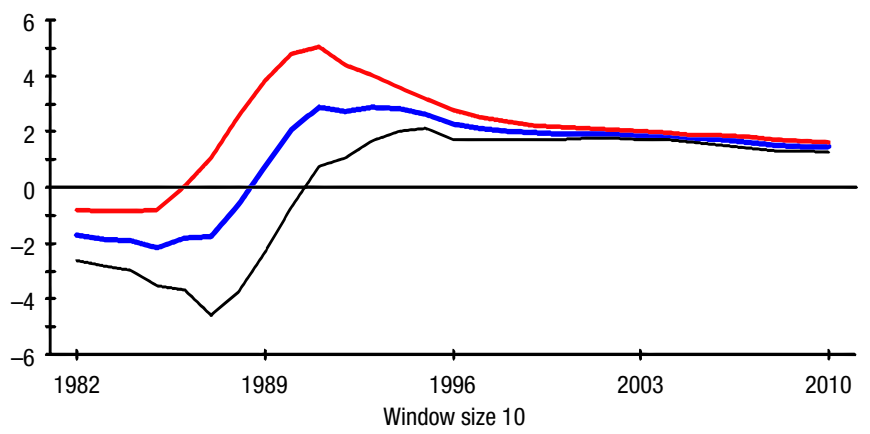

Fig. 3. Coefficient of FDI and its two S.E. bands based on rolling OLS (Dependent Variable: PS)

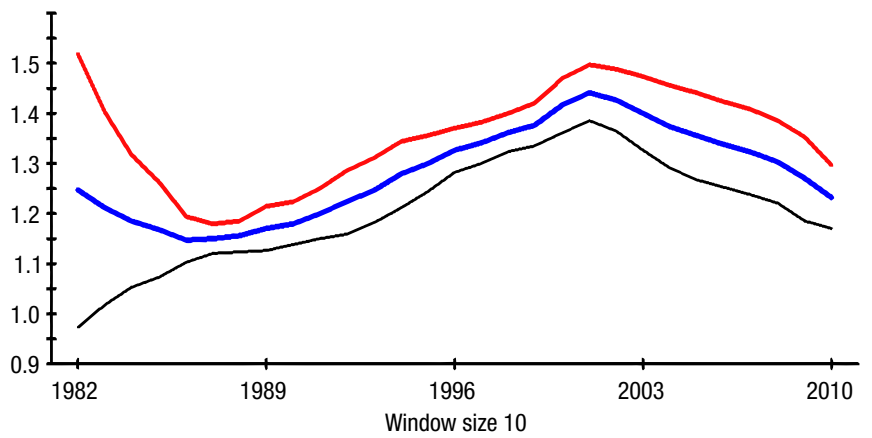

Fig. 4. Coefficient of REM and its two S.E. bands based on rolling OLS (Dependent Variable: PS)

Two standard deviation bands show the upper and lower bounds. Results of Figure 3 indicate that the coefficient of considered variable FDI remains negative from 1982 to 1988. But from 1988 to 2010 the coefficient of FDI remains positive. Results of Figure 4 shows that the coefficient of workers' remittances having positive coefficients throughout the sample period. The coefficient of workers' remittances is continuously increasing from 1986 to 2001. But from 2001 to 2010 the coefficient of workers' remittance is continuously decreasing.

\section{Stability of short run model}

The stability of the short run model in the sample size is evaluated by using the cumulative sum (CUSUM) and CUSUM of square test on the recursive residuals. CUSUM test detects systematic changes from the coefficients of regression, while, CUSUM of 
square test is able to detect the sudden changes from constancy of regression coefficients (Brown et al. 1975).

Figure 5 and 6 represents the results of the CUSUM and CUSUM of square tests respectively. Results indicate that the statistics of both CUSUM and CUSUM of square test are lying within the interval bands at $5 \%$ confidence interval. Results suggest that there is no structural instability in the residuals of equation of private savings.

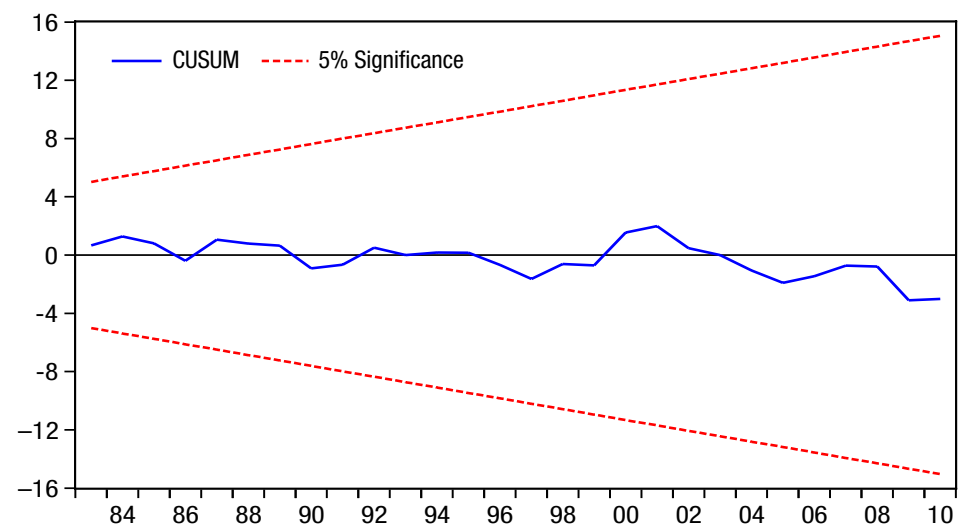

Fig. 5. Plot of cumulative sum of recursive residuals. The straight lines represent critical bounds at $5 \%$ significance level

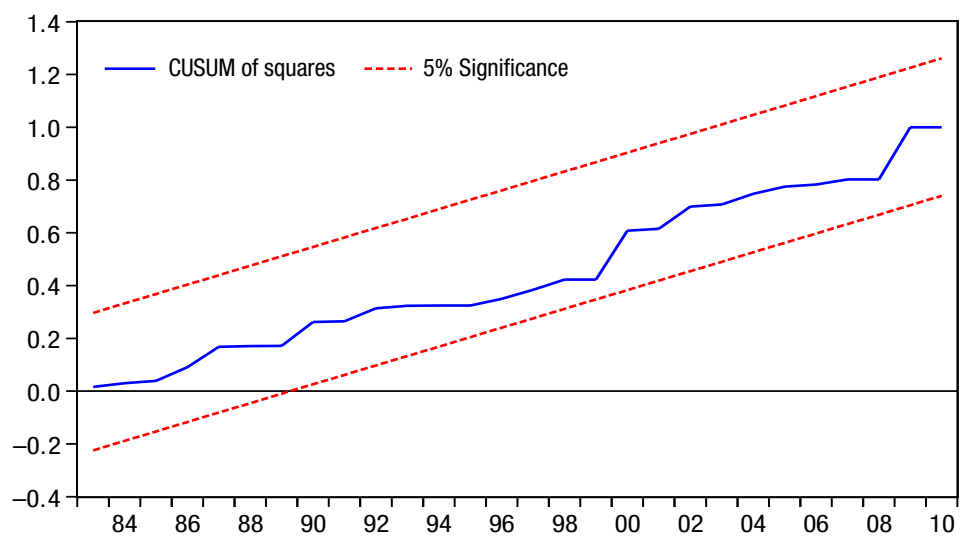

Fig. 6. Plot of cumulative sum of squares of recursive residuals. The straight lines represent critical bounds at $5 \%$ significance level 


\section{Causality analysis}

In this section three different techniques of causal analysis, namely, Granger causality analysis ${ }^{10}$, Toda and Yamamoto modified Wald test causality analysis ${ }^{11}$ and variance decomposition method ${ }^{12}$ to analyze the robustness of causal relationship between foreign capital inflows and private savings.

\subsection{Granger causality analysis}

The direction of causality between dependent and independent variables is analyzed by Granger (1969) causality test. We determine the causality analysis of our private saving model on lag one. Jones (1989) favors the ad hoc selection method for lag length in the Granger causality test over some of other statistical method to determine the optimal lag. The equation of the Granger causality model is given below:

$$
\begin{aligned}
& Y=\sum_{i=1}^{t} \alpha_{i} X_{t-i}+\sum_{i=1}^{t} \beta_{i} Y_{t-i}+\mu ; \\
& X=\sum_{i=1}^{t} \lambda_{i} X_{t-i}+\sum_{i=1}^{t} \delta_{i} Y_{t-i}+v .
\end{aligned}
$$

It is assumed that $\mu$ and $v$ are uncorrelated. There are two variables and dealt with bilateral causality. Above equation states that $Y$ is related to its lag values and $X$ is related to its lag values.

Table 7. Results of Granger causality test

\begin{tabular}{ccc}
\hline Variables & F-Statistic & Probability \\
\hline PS does not Granger cause FDI & 11.100 & 0.000 \\
\hline FDI does not Granger cause PS & 3.284 & 0.035 \\
\hline PS does not Granger cause REM & 4.178 & 0.049 \\
\hline REM does not Granger cause PS & 3.426 & 0.073 \\
\hline
\end{tabular}

Note: The lag length is 1 .

The results of the Granger causality test are reported in Table 7. Results show the bidirectional causal relationship of FDI and workers' remittances with private savings.

\subsection{Toda and Yamamoto modified Wald test causality analysis}

The direction of causality between dependent and independent variables is analyzed by using the causality test based on Toda and Yamamoto (1995) procedure. This test uses a modified Wald $(M W A L D)$ test which can be applies irrespective of the of whether underlying variables are purely $I(0), I(1)$ or mutually co-integrated. Toda and Yama-

\footnotetext{
${ }^{10}$ See Granger (1969).

${ }^{11}$ See Toda and Yamamoto (1995).

12 The variance decomposition method is estimated through VAR framework, it shows the proportion contribution in one variable caused by the shocks in other variables (Pesaran, Shin 1998).
} 
moto (1995) augmented Granger causality test uses the Seemingly Unrelated Regression $(S U R)$ technique through estimating a two equation system. The Wald test improves efficiency when $S U R$ models are used in the estimation. So, the model can be specified as follows:

$$
\begin{aligned}
& Y_{t}=\alpha_{1}+\sum_{i=1}^{k+d} \gamma_{1 i} Y_{t-i}+\sum_{t-i}^{k+d} \gamma_{2 i} X_{t-i}+\varepsilon_{y t} \\
& X_{t}=\alpha_{2}+\sum_{i=1}^{k+d} \delta_{1 i} Y_{t-i}+\sum_{t-i}^{k+d} \delta_{2 i} X_{t-i}+\varepsilon_{x t},
\end{aligned}
$$

where $k$ is the optimal lag order, $d$ is the maximum order of integration of the series in the system, $\varepsilon_{y t}$ and $\varepsilon_{x t}$ are error terms that are assumed to be white noise. Usual Wald tests are then applied to the first $k$ coefficient matrices using the standard $\chi^{2}-$ statistics.

Table 8. Results of Toda and Yamamoto causality test

\begin{tabular}{ccccc}
\hline \multirow{2}{*}{ Dependent variable } & \multicolumn{3}{c}{ Modified Wald - statistics } \\
\cline { 2 - 4 } & PS & FDI & REM \\
\hline PS & - & 6.676 & 4.594 \\
\cline { 2 - 3 } & & & $(0.018)$ & $(0.019)$ \\
\hline FDI & 8.874 & - & 0.464 \\
\cline { 2 - 3 } & $(0.006)$ & & $(0.709)$ \\
\hline REM & 3.324 & 0.425 & - \\
\cline { 2 - 3 } & $(0.079)$ & $(0.658)$ & \\
\hline
\end{tabular}

Note: The lag length for $P S$ is 2, FDI is 1 and REM is 1 . As per SBC criteria.

The results of Toda and Yamamoto (1995) based causality test are reported in Table 8 . Results indicate the bidirectional causal relationship of FDI and workers' remittances with private savings.

\subsection{Variance decomposition analysis}

Generalized forecast error variance decomposition method under vector autoregressive (VAR) system has been used to analyze the strength of the causal relationship between FDI, workers' remittances and private savings. The variance decomposition method provides the magnitude of the predicted error variance for a series accounted for by innovations from each of the independent variable over different time periods. Table 9 represents the results of variance decomposition analysis.

Results of Table 9 show that in the first round the change in private savings, explain completely by its own innovations. In the second period, $95.90 \%$ explain by own innovation, $2.27 \%$ by FDI innovation and $1.83 \%$ by workers' remittances innovation. In period five, the shocks in private savings explain $76.80 \%$ by own innovation, $10.56 \%$ by innovations of FDI and $12.64 \%$ by innovations of workers' remittances. In tenth period, the shocks in private savings explain $30.80 \%$ by own shocks, while $37.56 \%$ explain by innovations of FDI and $31.64 \%$ explain by innovations of workers' remittances. 
Table 9. Results of variance decomposition approach

\begin{tabular}{|c|c|c|c|}
\hline Period & PS & FDI & REM \\
\hline \multicolumn{4}{|c|}{ Variance decomposition of PS } \\
\hline 1 & 100.000 & 0.000 & 0.000 \\
\hline 2 & 95.904 & 2.266 & 1.830 \\
\hline 3 & 91.744 & 3.980 & 4.276 \\
\hline 4 & 84.274 & 6.869 & 8.858 \\
\hline 5 & 76.803 & 10.557 & 12.640 \\
\hline 6 & 66.274 & 14.869 & 18.858 \\
\hline 7 & 61.569 & 18.032 & 20.399 \\
\hline 8 & 46.428 & 29.062 & 24.510 \\
\hline 9 & 38.929 & 33.877 & 27.194 \\
\hline 10 & 30.803 & 37.557 & 31.640 \\
\hline \multicolumn{4}{|c|}{ Variance decomposition of FDI } \\
\hline 1 & 0.026 & 99.974 & 0.000 \\
\hline 2 & 0.061 & 99.939 & 0.001 \\
\hline 3 & 5.004 & 94.940 & 0.057 \\
\hline 4 & 8.557 & 91.315 & 0.128 \\
\hline 5 & 13.975 & 85.901 & 0.124 \\
\hline 6 & 18.182 & 81.641 & 0.177 \\
\hline 7 & 22.245 & 77.277 & 0.479 \\
\hline 8 & 25.353 & 73.555 & 1.092 \\
\hline 9 & 27.942 & 70.131 & 1.927 \\
\hline 10 & 29.949 & 67.211 & 2.840 \\
\hline \multicolumn{4}{|c|}{ Variance decomposition of REM } \\
\hline 1 & 12.488 & 2.394 & 85.118 \\
\hline 2 & 8.357 & 2.171 & 89.472 \\
\hline 3 & 10.967 & 2.501 & 86.532 \\
\hline 4 & 13.475 & 2.803 & 83.722 \\
\hline 5 & 16.795 & 2.853 & 80.352 \\
\hline 6 & 19.326 & 2.773 & 77.902 \\
\hline 7 & 21.146 & 2.749 & 76.105 \\
\hline 8 & 22.157 & 2.905 & 74.938 \\
\hline 9 & 22.776 & 3.222 & 74.002 \\
\hline 10 & 23.216 & 3.620 & 73.164 \\
\hline
\end{tabular}

The shocks in FDI explain $0.03 \%, 13.98 \%$ and $29.95 \%$ by innovation of private savings in the period 1, 5 and 10 respectively. The shocks in workers' remittances explain $12.49 \%, 16.76 \%$ and $23.22 \%$ by innovation of private savings in the period 1,5 and 10 respectively. These findings suggest the bidirectional causal relationship of FDI and workers' remittances with private savings. 


\section{Conclusions}

This paper makes a unique contribution to the literature with reference to Pakistan, being a pioneering attempt to investigate the impact of FDI and workers' remittances on private savings of Pakistan by using the long annual time series data for 39 years from 1973 to 2011 and by applying more rigorous econometric techniques. ARDL bound testing cointegration approach confirms the valid of a long run relationship between foreign capital inflows and private savings. Results indicate the significant positive impact of FDI and workers' remittances on private savings in the long run as well as in the short run. Results of Granger causality test, Toda and Yamamoto Modified Wald causality test and variance decomposition test confirm the bidirectional causal relationship of FDI and workers' remittances with private savings.

FDI, workers' remittances and private savings are connected in a complementary way in Pakistan. It is recommended that government and policy makers should form friendly policies to attract more FDI and workers' remittances in the country which leads to increase private savings and domestic investment opportunities in the country. One of the best destinations of inward FDI is the export processing zone (EPZ) in any country. EPZ benefits the host country by utilizing location specific assets. This inward FDI may enhance technological know-how, training of local workforce and this increase export competitiveness.

The comparative study with neighboring countries should be done in the near future to comparatively analyze the influence of FDI and remittances in the South Asian countries.

\section{References}

Adams, R. H. 1998. Remittances, investment, and rural asset accumulation in Pakistan, Economic Development and Cultural Change 47: 155-173. http://dx.doi.org/10.1086/452390

Ahmad, M. H.; Ahmed, Q. M. 2002. Foreign capital inflows and domestic savings in Pakistan: cointegration techniques and error correction modeling, The Pakistan Development Review 41(4): 825-836.

Azam, M.; Shakeel, K. 2012. Impact of foreign capital inflows on household saving in Pakistan, European Journal of Scientific Research 68(3): 345-351.

Bashier, A.; Bataineh, T. 2007. The casual relationship between foreign direct investment and saving in Jordan, International Management Review 3(4): 12-18.

Bayar, Y. 2014. Savings, foreign direct investment inflows and economic growth in emerging Asian economies, Asian Economic and Financial Review 4(8): 1106-1122.

Becker, G. 1974. A theory of social interaction, Journal of Political Economy 74: 399-405. http://dx.doi.org/10.1086/260265

Blomstrom, M.; Kokko, A. 1998. Multinational corporations and spillovers, Journal of Economic Surveys 12(3): 247-277. http://dx.doi.org/10.1111/1467-6419.00056

Borensztein, E.; Gregorio, J. D.; Lee, J. W. 1998. How does foreign direct investment affect economic growth? Journal of International Economics 45: 115-135.

http://dx.doi.org/10.1016/S0022-1996(97)00033-0

Bowles, P. 1987. Foreign aid and domestic savings in less developed countries: some tests for causality, World Development 15(6): 789-796. http://dx.doi.org/10.1016/0305-750X(87)90060-X 
Brown, R. L.; Durbin, J.; Ewans, J. M. 1975. Techniques for testing the constance of regression relations overtime, Journal of Royal Statistical Society 37: 149-172.

Chenery, H.; Strout, A. 1966. Foreign assistance and economic development, American Economic Review 56(4).

Dickey, D. A.; Fuller, W. A. 1979. Distribution of the estimators for autoregressive time series with a unit root, Journal of the American Statistical Association 74: 427-431.

Dunning, J. H. 1997. The European internal market programme and inbound foreign direct investment, Journal of Common Market Studies 35(2): 189-223.

http://dx.doi.org/10.1111/1468-5965.00048

Edwards, S. 1995. Why are saving rates so different across countries? An international comparative analysis, NBER working paper No. 5097. National Bureau of Economic Research, Cambridge.

Edwards, S. 1996. Why are Latin American's savings rates so low? An international comparative analysis, Journal of Development Economics 51: 5-44.

http://dx.doi.org/10.1016/S0304-3878(96)00424-5

Faridi, M. Z.; Arif, M. A. 2012. Globalization and saving behavior of Pakistan: an empirical analysis, Pakistan Journal of Social Sciences 32(1): 77-91.

Gilani, I.; Khan, F.; Iqbal, M. 1981. Labor migration from Pakistan to the Middle East and its impact on the domestic economy, Part 1, Islamabad, Pakistan Institute of Economic Development Research Report Series 126.

Granger, C. W. J. 1969. Investigating causal relations by econometric models and cross-spectral methods, Econometrica 37(3): 424-438. http://dx.doi.org/10.2307/1912791

Hachicha, N. 2003. Foreign capitals-national savings dynamics in Tunisia: evidence from co-integration, weak exogeneity and simultaneous error correction modeling, International Economic Journal 17(4): 43-60.

Haug, A. 2002. Temporal aggregation and the power of co-integration tests: a Monte Carlo study, Oxford Bulletin of Economics and Statistics 64: 399-412.

http://dx.doi.org/10.1111/1468-0084.00025

Janicki, H. P.; Wunnava, P. V. 2004. Determinants of foreign direct investment: empirical evidence from EU accession candidates, Applied Economics 36: 505-509.

http://dx.doi.org/10.1080/00036840410001682214

Jawaid, S. T.; Raza, S. A. 2014. Effects of workers' remittances and its volatility on economic growth in South Asia, International Migration. http://dx.doi.org/10.1111/imig.12151

Jawaid, S. T.; Raza, S. A. 2012. Workers' remittances and economic growth in China and Korea: an empirical analysis, Journal of Chinese Economic and Foreign Trade Studies 5(3): 185-193. http://dx.doi.org/10.1108/17544401211263946

Jones, J. D. 1989. A comparison of lag length selection techniques in tests of Granger causality between money growth and inflation: evidence from the US: 1959-86, Applied Economics 21(6): 809-822. http://dx.doi.org/10.1080/758520275

Kapur, D.; McHale, J. 2003. Migration's new payoff, Foreign Policy 139: 48-57.

http://dx.doi.org/10.2307/3183737

Katircioglu, S. T.; Naraliyeva, A. 2006. Foreign direct investment, domestic savings and economic growth in Kazakhstan: evidence from cointegration and causality tests, Investment Management and Financial Innovations 3(2): 34-45.

Khan, R. E. A.; Hye, Q. M. A. 2010. Financial sector reforms and household savings in Pakistan: an ARDL approach, African Journal of Business Management 4(16): 3447-3456.

http://dx.doi.org/10.2139/ssrn.2567414 
Kindleberger, C. P. 1969. American business abroad: six lectures on direct investment. New Haven: Yale University Press.

Lipsey, R.; Sjöholm, F. 2004. FDI and wage spillovers in Indonesian manufacturing, Review of World Economics (Weltwirtschaftliches Archiv) 140(2): 321-332.

http://dx.doi.org/10.1007/BF02663651

Lyroudi, K.; Papanastasiou, J.; Vamvakidis, A. 2004. Foreign direct investment and economic growth in transition economies, South Eastern Europe Journal of Economics 2(1): 97-110.

Nair-Reichert, U.; Weinhold, D. 2001. Causality tests for cross-country panels: a new look on FDI and economic growth in developing countries, Oxford Bulletin of Economics and Statistics 63: 153-171. http://dx.doi.org/10.1111/1468-0084.00214

Oladipo, O. S. 2010. Does saving really matter for economic growth in developing countries? The case of a small open economy, International Business \& Economics Research Journal 9(4): 87-94.

Pesaran, M. H.; Pesaran, B. 1997. Working with Microfit 4.0: interactive econometric analysis. Oxford: Oxford University Press.

Pesaran, M. H.; Shin, Y. 1998. Generalized impulse response analysis in linear multivariate models, Economic Letters 58(1): 17-29. http://dx.doi.org/10.1016/S0165-1765(97)00214-0

Pesaran, M. H.; Shin, Y. 1999. An autoregressive distributed lag modeling approach to co-integration analysis, in S. Strom (Ed.). Econometrics and economic theory in the 20th century: the Ragnar Frisch centennial symposium. Cambridge: Cambridge University Press.

http://dx.doi.org/10.1017/CCOL521633230.011

Pesaran, M. H.; Shin, Y.; Smith, R. J. 2000. Structural analysis of vector error correction models with exogenous I(1) variables, Journal of Econometrics 97: 293-343.

http://dx.doi.org/10.1016/S0304-4076(99)00073-1

Pesaran, M. H.; Shin, Y.; Smith, R. J. 2001. Bounds testing approaches to the analysis of level relationships, Journal of Applied Economics 16: 289-326. http://dx.doi.org/10.1002/jae.616

Phillips, P. B.; Perron, P. 1988. Testing for a unit root in time series regression, Biometrika 75 : 335-346. http://dx.doi.org/10.1093/biomet/75.2.335

Pradhan, R. P. 2010. Financial deepening, foreign direct investment and economic growth: are they cointegrated, International Journal of Financial Research 1(1): 37-43.

http://dx.doi.org/10.5430/ijfr.v1n1p37

Raza, S. A.; Shahbaz, M.; Nguyen, D. K. 2015. Energy conservation policies, growth and trade performance: evidence of feedback hypothesis in Pakistan, Energy Policy 80: 1-10.

http://dx.doi.org/10.1016/j.enpol.2015.01.011

Raza, S. A.; Jawaid, S. T. 2012. Foreign capital inflows, economic growth and stock market capitalization in Asian countries: an ARDL bound testing approach, Quality and Quantity 48(1): 375-385. http://dx.doi.org/10.1007/s11135-012-9774-4

Russel, S. S. 1986. Remittances from international migration: a review in perspective, World Development 14(6): 677-696. http://dx.doi.org/10.1016/0305-750X(86)90012-4

Salahuddin, M.; Shahbaz, M.; Chani, M. I. 2010. A note on causal relationship between FDI and savings in Bangladesh, Theoretical and Applied Economics 17(11): 53-62.

Shahbaz, M.; Awan, R.U.; Ali, L. 2008. Bi-directional causality between FDI and savings: a case study of Pakistan, International Research Journal of Finance and Economics 17: 75-83.

Sofranko, A. J.; Idris, K. 1999. Use of overseas migrants' remittances to the extended family for business investment: a research note, Rural Sociology 64(3): 464-481.

http://dx.doi.org/10.1111/j.1549-0831.1999.tb00362.x 
Toda, H. Y.; Yamamoto, T. 1995. Statistical inference in vector autoregressions with possibly integrated processes, Journal of Econometrics 66: 225-250.

http://dx.doi.org/10.1016/0304-4076(94)01616-8

Zhang, K. H. 2001. Does foreign direct investment promote economic growth? Evidence from East Asia and Latin America, Contemporary Economic Policy 19(2): 175-185.

http://dx.doi.org/10.1111/j.1465-7287.2001.tb00059.x

Syed Ali RAZA is associated with IQRA University as a Lecturer and Manager Research \& Publications. His areas of interest include financial economics and corporate finance. He has published the papers in the research journals like Energy Policy, Economic Modelling, Social Indicators Research, Quality and Quantity, International Migration, Total Quality Management and Business Excellence, Journal of Transnational Management, Transition Studies Review, Global Business Review and Journal of Chinese Economic and Foreign Trade Studies. 